\title{
Strategi Pengembangan Potensi Wisata Desa Bukit Telago Dalam Perspektif Community Based Tourism
}

\author{
Juardi $^{\text {a,1,* }}$, Deni Handani ${ }^{\text {b,2 }}$, Sukarni Novita Sari ${ }^{\text {b,3 }}$ \\ ${ }^{a}$ Program Studi Administrasi Bisnis, Institut Stiami \\ ${ }^{\mathrm{b}}$ Program Studi Administrasi Bisnis, Sekolah Tinggi Ilmu Administrasi Setih Setio Muara Bungo \\ ${ }^{c}$ Program Studi Administrasi Bisnis, Fakultas Ilmu Administrasi Institut Stiami \\ 1 juardi703@gmail.com*; ${ }^{2}$ denihandani91@ gmail.com; ${ }^{3}$ novitasarisukarni@gmail.com \\ * corresponding author
}

\section{ABSTRACT}

The purpose of this research is to determine the extent of community involvement at the village of Bukit Telago and how the strategy of developing tourism at the village of Bukit Telago. Descriptive qualitative is the methodology used in this study. With 30 samples consisting of officials, community and local entrepreneurs, the method of sampling is use purposive sampling and random sampling methods. The results are that community involvement at Bukit Telago tourism was only in communities around the village and the development strategy used involves three pillars namely village, community and local businessmen who are mutually integrated.

\section{Pendahuluan}

\subsection{Latar Belakang}

Clare (2002) mengatakan bahwa Pariwisata adalah keseluruhan rangkaian kegiatan yang berhubungan dengan gerakan manusia melakukan perjalanan atau persinggahan sementara dari tempat tinggalnya kesuatu tempat atau beberapa tempat tujuan diluar lingkungan tempat tinggal yang didorong oleh beberapa keperluan tanpa maksud mencari nafkah. Di dalam pariwisata di Indonesia, kekayaan alam dan budaya merupakan komponen penting, Indonesia yang memiliki iklim tropis yang memiliki 14.572 pulau. Salah satu faktor penggerak ekonomi masyarakat ialah melalui sektor pariwisata. Pariwisata merupakan bonus geografi bagi sebagian wilayah yang ada di Indonesia yang harus dilestarikan dan dikembangkan.

Keadaan lingkungan yang semakin memprihatinkan saat ini menjadi pendorong untuk melestarikan sumberdaya alam yang ada, terlebih pembabatan hutan secara liar dan pencemaran lingkungan, tanpa memperhatikan kaidah lingkungan dapat merusak potensi pariwisata yang ada saat ini. Namun kenyaatan ini tanpa didukung oleh kesadaran manusia akan kepedulian terhadap ekosistem yang ada.

Bagi perkembangan wilayah secara global, pariwisata menjadi salah satu sektor yang menjanjikan Kondisi wilayah yang masih alami, tidak hanya mengembangkan aspek lingkungan dalam hal konsevasi, tetapi juga memberikan keuntungan kepada masyarakat sekitar, adalah sebagai salah satu upaya pengembangan pedesaaan untuk meningkatkan perekonomian lokal, dimana masyarakat adalah pemegang kendali utama.

Konsep pengembangan pariwisata berbasis masyarakat sudah mulai banyak dikembangkan diseluruh wilayah di Indonesia, hal ini dikarenakan masyarakat pedesaan mulai menyadari akan potensi yang ada diwilayah sekitar.

\subsection{Urgensi Pengembangan Pariwisata Lokal}


Seiring dengan perkembangan teknologi, potensi lokal yang semakin meningkat kini mulai diekspos melalui media sosial. Selama ini wisata lokal kurang mendapat respon dikarenakan kurangnya informasi tentang kekayaan alam di suatu wilayah. Di Sumatera, khususnya, pengembangan wisata berbasis desa wisata mulai dilirik seiiring dengan kearifan lokal di desa mulai berkembang dan sudah bisa menerima kehadiran masyarakat dari luar desa. Pengembangan desa wisata dapat meningkatkan ekonomi masyarakat sekitar, hal ini dikarenakan masyarakat sebagai leading sector sasaran pengembangan wisata tersebut. Di Indonesia pengembangan wisata berbasis pedesaan semakin berkembang, karena maanfaat yang dirasakan masyarakat akibat dari pengembangan tersebut. Untuk itu maka dirasa sangat perlu untuk mengembangkan wisata di pedesaan.

\subsection{Desa Wisata}

Damanik (2013: 69) menyatakan kalau pengembangan pariwisata pedesaan didorong oleh tiga faktor. Pertama, wilayah pedesaan memiliki potensi alam dan budaya yang relatif lebih otentik daripada wilayah perkotaan, masyarakat pedesaan masih menjalankan tradisi dan ritual-ritual budaya dan topografi yang cukup serasi. Kedua, wilayah pedesaan memiliki lingkungan fisik yang relatif masih asli atau belum banyak tercemar oleh ragam jenis polusi dibandingankan dengan kawasan perkotaan. Ketiga, dalam tingkat tertentu daerah pedesaan menghadapi perkembangan ekonomi yang relatif lambat, sehingga pemanfaatan potensi ekonomi, sosial dan budaya masyarakat lokal secara optimal merupakan alasan rasional dalam pengembangan pariwisata pedesaan.

Kebudayaan adalah salah satu yang menarik di kawasan tersebut. Kondisi inilah yang mendasari terciptanya kegiatan pariwisata di suatu desa karena kekhasan budaya masyarakat yang mendiami daerah tersebut.

Hadiwijoyo (2012) mengatakan bahwa:

1. Aksesbilitasnya baik, sehingga mudah dikunjungi wisatawan dengan menggunakan berbagai jenis alat transportasi.

2. Memiliki obyek-obyek menarik berupa alam, seni budaya, legenda, makanan lokal, dan sebagainya untuk dikembangkan sebagai obyek wisata.

3. Masyarakat dan aparat desanya menerima dan memberikan dukungan yang tinggi terhadap desa wisata serta para wisatawan yang datang ke desanya.

4. Keamanan di desa tersebut terjamin.

5. Tersedia akomodasi, telekomunikasi, dan tenaga kerja yang memadai.

6. Beriklim sejuk atau dingin.

7. Berhubungan dengan obyek wisata lain yang sudah dikenal oleh masyarakat luas.

Pengelolaan di dalam pariwisata ini diadopsi dari konsep yang dikembangkan oleh Pitana dan Diarta (2009) yang dimulai dari pengelolaan sumberdaya pariwisata. Pengelolaan sumberdaya pariwisata adalah cara mencapai tujuan pariwisata yang berkelanjutan secara sosial, ekonomi, dan lingkungan. maka dengan demikian pengelola wajib melakukan manajemen sumberdaya yang efektif. Manajemen sumber daya digunakan untuk menjamin perlindungan terhadap ekosistem dan degradasi kualitas lingkungan.

Suatu wilayah pedesaan yang menawarkan keaslian baik dari segi sosial budaya, adat-istiadat, keseharian, arsitektur tradisional, struktur tata ruang bisa disebut sebagai desa wisata, di mana desa tersebut disajikan dalam suatu suatu bentuk integrasi komponen pariwisata seperti atraksi, akomodasi dan fasilitas pendukung.

\subsection{Community Based Tourism}

Suansri (2003: 14), berpendapat, Community Based Tourism adalah pariwisata yang menitikberatkan keberlanjutan lingkungan, sosial, dan budaya kedalam satu kemasan. Hal ini dikelola dan dimiliki oleh masyarakat, untuk masyarakat, dengan tujuan memungkinkan pengunjung untuk meningkatkan kesadaran mereka dan belajar tentang masyarakat dan lokal cara hidup".

Suansri (2003:12) mengemukakan Community Based Tourism merupakan paradigma baru dalam pengelolaan pariwisata didalamnya ada 10 (sepuluh prinsip yang harus dipegang teguh dalam pelaksanaan Community Based Tourism, antara lain: 
a. Mengakui dan mendukung serta mengembangkan kepemilikan komunitas dalam industri pariwisata.

b. Mengikutsertakan anggota komunitas dalam memulai setiap aspek.

c. Mengembangkan kebanggaan komunitas.

d. Mengembangkan kualitas hidup komunitas.

e. Menjamin keberlanjutan lingkungan.

f. Mempertahankan keunikan karakter dan budaya di area lokal.

g. Membantu berkembangnya pembelajaran tentang pertukaran budaya pada komunitas.

h. Menghargai perbedaan budaya dan martabat manusia.

i. Mendistribusikan keuntungan secara adil pada komunitas.

j. Berperan dalam menentukan presentase pendapatan.

Kesimpulkan dari 10 (sepuluh) prinsip pengelolaan Community Based Tourism adalah: Pertama, prinsip keikutsertaan anggota komunitas kedalam setiap kegiatan pariwisata. Kedua, prinsip menjaga lingkungan hidup. Ketiga adalah prinsip kelestarian budaya. Keempat adalah prinsip pemerataan pendapatan

\subsection{Bukit Telago Sebagai Salah Satu Potensi Wisata}

Menurut Hadiwijoyo (2012:68), desa wisata adalah suatu kawasan pedesaan yang menawarkan keseluruhan suasana yang mencerminkan keaslian perdesaan baik dari kehidupan sosial ekonomi, sosial budaya, adat istiadat, keseharian, memiliki arsitektur bangunan dan struktur tata ruang desa yang khas, atau kegiatan perekonomian yang unik dan menarik serta mempunyai potensi untuk dikembangkannya berbagai komponen kepariwisataan, misalnya atraksi, akomodasi, makananminuman dan kebutuhan wisata lainnya.

Keindahan alam adalah anugerah dari Allah SWT, di mana kita sebagai manusia mempunyai tanggung jawab untuk menjaga dan melestarikannya. Akan tetapi harus diiringi dengan kemampuan mengelola potensi alam yang sudah ada oleh elemen masyarakat terkait. Mengelola potensi alam butuh keseriusan dari pihak pemerintah daerah yang bersangkutan, karena dengan adanya pengelolaan yang baik maka akan berdampak dengan ekonomi masyarakat sekitar. Penguatan ekonomi masyarakat akan berdampak positif pula bagi pemerintah daerah setempat. Akan tetapi kesadaran masyarakat akan potensi yang ada harus sejalan dengan sumberdaya manusia yang ada untuk pemanfaatan pengelolaan potensi tersebut.

Berkaitan dengan hal tersebut kawasan Desa Bukit Telago berada di Kabupaten Bungo, Kecamatan Pelepat, sekitar 18 kilometer dari pusat Kota Bungo, mempunyai potensi wisata yang bisa dikembangkan. Akan tetapi hal tersebut belum dikembangkan secara optimal, karena keterbatasan sumber daya manusia dan dorongan dari Pemerintah Desa dan Pemerintah Daerah. Tentunya hal tersebut harus ada kemauan yang kuat dari masyarakat tentang potensi yang ada dan semua elemen masyarakat harus bisa memanfaatkan dengan baik diperlukan manajemen yang baik pula.

Salah satu upaya yang telah dilakukan oleh Desa Bukit Telago ialah membentuk kelompok (komunitas) untuk pengelolaan wisata akan tetapi hasilnya belum maksimal, dikarenakan kualitas sumber daya manusia yang masih terbatas, untuk itu perlunya memberikan pelatihan dasar mengenai pengelolaan wisata alam tanpa merusak lingkungan sekitar. Selaras dengan pengembangan wisata alam tersebut diperlukan ide dan gagasan guna memanfaatkan potensi yang ada serta menjadi daya tarik wisatawan.

Adapun potensi yang ada adalah obyek wisata alam yang memiliki banyak batu alam yang memperindah kawasan obyek wisata, puncak bukitnya yang luas bisa dimanfaatkan untuk perkemahan, tebing bukit memiliki potensi untuk wisata petualangan sekaligus area olahraga panjat tebing, lahan pertanian masyarakat, sungai kecil berbatu dan telaga yang ada di dalam gua serta wisata budaya terkait nilai-nilai adat, peran penting masyarakat lokal dalam pengembangan desa wisata karena potensi alam serta keunikan tradisi dan budaya yang melekat pada komunitas tersebut merupakan unsur utama kegiatan desa wisata. Komunitas lokal yang tumbuh dan hidup berdampingan dengan suatu objek wisata akan menjadi bagian dari sistem ekologi yang saling terkait. 
Menurut Wearing (2001), keberhasilan pengembangan desa wisata tergantung pada tingkat penerimaan dan dukungan masyarakat lokal. Ilustrasi dari Wearing (2001) adalah masyarakat lokal berperan sebagai tuan rumah dan menjadi pelaku penting dalam pengembangan desa wisata dalam keseluruhan tahapan mulai tahap perencanaan, pengawasan, dan implementasi. Ilustrasi tersebut menegaskan bahwa masyarakat lokal berkedudukan sama penting dengan pemerintah dan swasta sebagai salah satu pemangku kepentingan dalam pengembangan pariwisata.

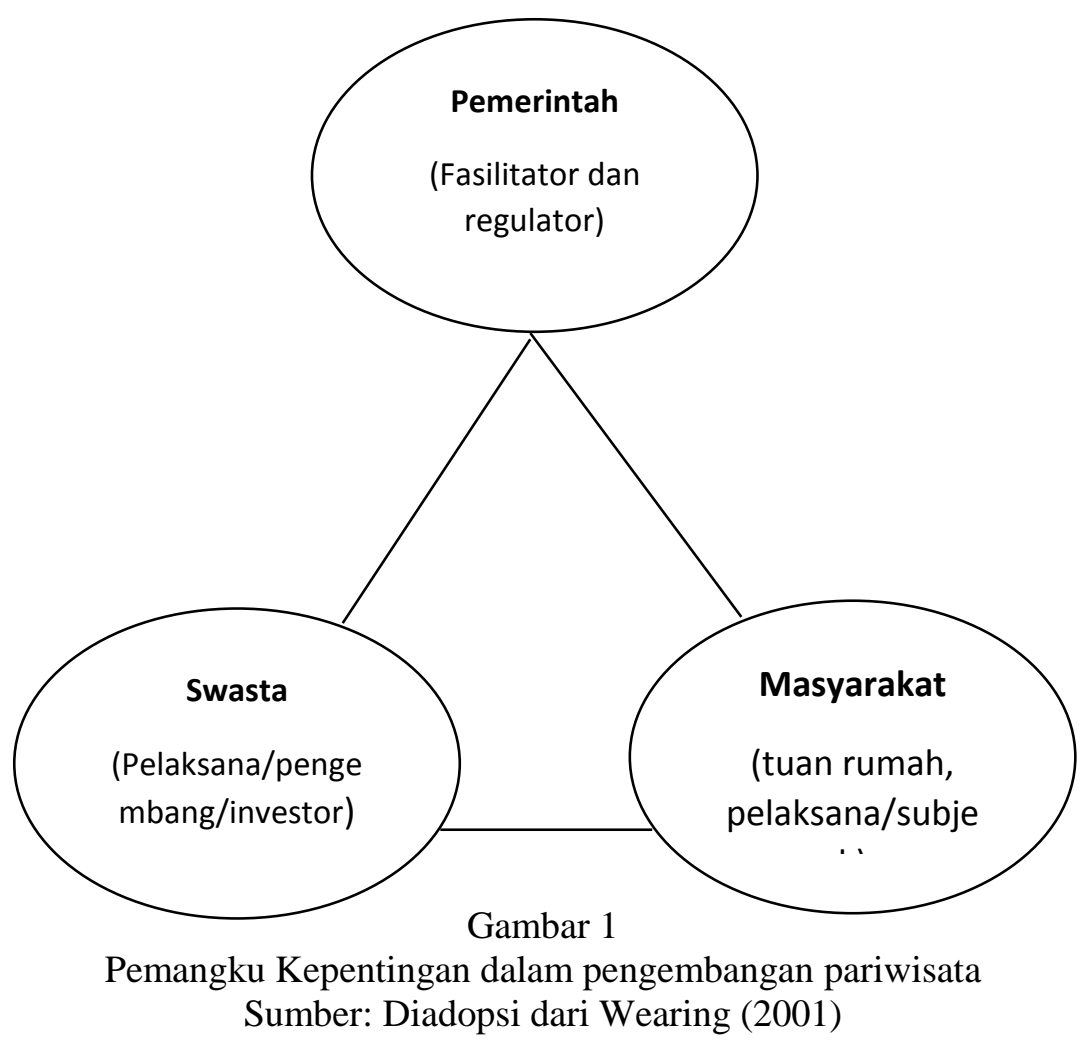

Mayoritas masyarakat Desa Bukit Telago sehari-hari berkerja sebagai petani karet dan sayursayuran dengan memanfaatkan lahan pertanian yang masih luas, akan tetapi komoditas pertanian belum beranekaragam, jika konsep wisata alam tersebut dapat di implemtasikan, maka komoditas petanian bisa beragam seperti jagung, singkong, kacang-kacangan dan lain-lain. Mengandalkan penghasilan sebagai petani karet belum mencukupi dalam memenuhi kebutuhan hidup yang semakin hari semakin tinggi.

Potensi alam yang ada tersebut dapat dikembangkan dengan membuat akses jembatan penyebrangan menuju kawasan wisata, dikarenakan jika musim hujan askes jalan tersebut tergenang banjir. Dengan adanya jembatan penyebrangan yang memadai diharapkan dapat mengatasi masalah tersebut agar akses menuju Puncak Telago menjadi lancar dan menambah nilai tambah bagi masyarakat sekitar.

Pengelolaan sumberdaya alam harus didukung oleh sumberdaya manusia yang baik serta membuat perencanaan yang matang, mulai dari perencanaan sampai dengan anggaran perlu dikaji secara komprehesif serta pengelolaan jangka panjang. Potensi yang ada di Bukit Telago ialah sebuah bukit yang asri serta memiliki pemandangan alam yang indah memanjakan mata pengunjung dengan melihat sunset dan sunrise. Kemudian bagi pecinta panjat tebing disuguhkan dengan tebing yang indah serta sungai tembulun, air terjun dan telaga yang ada didalam bukit.

Jika potensi tersebut bisa dikembangkan dengan baik, maka ekonomi masyarakat akan tumbuh dengan memanfaatkan lahan kosong dengan menanam jagung, ubi kayu dan lain-lain serta menggali ide-ide kreatif produk-produk olahan untuk oleh-oleh bagi pengunjung. Selama ini yang menjadi kendala dalam pengembangan potensi tersebut kurangnya sumberdaya manusia yang mampu mengelola dan tentunya peran pemerintah desa sangat dibutuhkan serta belum menemukan 
konsep wisata yang ditawarkan kepada pengunjung. Dengan adanya program pusat terhadap pembangunan desa diharapkan dana yang dikucurkan oleh pemerintah pusat dapat dimanfaatkan oleh desa dalam pengembangan potensi yang ada.

Dari penjabaran diatas maka penulis membuat rumusan masalah sebagai berikut:

1. Sejauh mana keterlibatan masyarakat dalam pengembangan wisata Desa Bukit Telago?

2. Bagaimana strategi pengembangan potensi wisata Desa Bukit Telago dalam prespektif Community Based Tourism?

\section{Metode Penelitian}

Menurut Hasan (2006: 19), metode penelitian terbagi menjadi metode pengumpulan data, metode pengumpulan sample dan metode analisis. Metode pengumpulan data menjadi metode pengumpulan data primer dan sekunder, dimana data primer dikumpulkan dengan metode observasi dan kuisioner, sedangkan data sekunder dikumpulkan melalui sumber-sumber yang telah ada seperti Biro Pusat Statistik, data dari kantor Desa Bukit Telago dan telaah dokumen.

Metode purposive sampling untuk menentukan nara sumber, yaitu Kepala Desa, Kepala Badan Lingkungan Hidup (KBLH) dan Kepala Bidang Pariwisata di Disporapar Kabupaten Bungo. Metode Random Sampling digunakan untuk menentukan responden kuisioner, yaitu 5 (lima) responden setiap Rukun Tetangga, sehingga total jumlahnya 30 (tiga puluh) responden.

Metode kualitatif dengan pendekatan deskriptif adalah metode analisis yang digunakan. Ruang lingkup dibatasi oleh penulis adalah fokus pada pengembangan potensi alam di Desa Bukit Telago seperti Puncak Bukit Telago, Sungai Temulun didalam Bukit Telago.

\section{Pembahasan}

Strategi Pengembangan Wisata Bukit Telago, memiliki 4 (empat) prinsip:

1. Prinsip keikutsertaan anggota komunitas kedalam setiap kegiatan pariwisata. Dengan adanya komitmen yang kuat dari berbagai unsur masyarakat dan pemerintah daerah, maka pengembangan potensi melibatkan komunitas pengelola wisata. Akan tetapi dalam hal ini masyarakat belum membentuk komonitas yang resmi batru sekumpulan anak anak asli desa yang mempromosikan melalui media online misalnya Face book, Instagram. Anak anak desa tersebut hendaknya mendapatkan pemahaman dan pelatihan terkait pengembangan wisata agar nantinya pengembangan tersebut dapat memberi dampak yang positif terhadap perkembangan desa dengan potensi yang dimiliki. Yang terjadi justru belum maksimal. Seharusnya masyarakat setempat secepatnya membentuk komunitas. Sehingga keterbatasan informasi yang memadai dapat teratasi dalam pengelolaan wisata pedesaan.

\section{Prinsip menjaga lingkungan hidup.}

Menurut Fatma, (2016) menyatakan bahwa Lingkungan hidup sama hal dengan dengan benda milik kita harus dijaga kelestariannya, dengan demikian akan terjaga dan tetap indah jika kita merasa bahwa lingkungan itu adalah milik kita. Ada 9 prinsip dalam menjaga lingkungan hidup.

- Prinsip sikap hormat terhadap alam (respect for nature)

Prinsip ini menunjukan bahwa semua mahluk hidup yang ada di alam ini mempunyai hak yang sama dengan kita sebagai manusia untuk itu kita dituntut untuk kesadaran untuk menjaganya. Contohnya melakukan reboisasi hutan, tidak menebang pohon secara sembarangan, dan menanam pohon/tanaman di lingkungan sekitar.

\section{- Prinsip tanggung jawab (moral responsibility for nature)}

Sebagai manusia yang memiliki akal budi sudah selayaknya menjaga seluruh mahluk atau benda yang ada di muka bumi ini sebagai rasa tanggungjawab sebagai pemimpin di alam. Contoh : Merasa perlu/harus merawat pohon dan tanaman dengan baik, menjaga kebersihan lingkungan sekitar dari sampah-sampah, serta tidak membuang sampah disembarang tempat. 
- Prinsip solidaritas kosmis (cosmic solidarity)

Prinsip solidaritas yang dimaksud di sini adalah hubungan yang harmonis antara manusia dengan alam, yang berfungsi untuk mengontrol perilaku manusia dalam batas-batas keseimbangan kosmis, serta mendorong manusia untuk mengambil kebijakan yang pro alam dan tidak setuju terhadap tindakan yang merusak alam. Contoh: Melakukan tebang pilih pohon, tidak mengeksploitasi sumber daya alam (SDA) secara berlebihan, serta memberikan sanksi yang tegas kepada pelaku yang merusak alam, seperti menebang pohon secara sembarangan.

- Prinsip kasih sayang dan kepedulian terhadap alam (caring for nature)

Karena benda benda yang ada di alam ini adalah milik kita maka hendaknya sikap, moral satu arah yang artinya tanpa mengharap balasan serta tidak didasarkan pada pertimbangan kepentingan pribadi melainkan untuk kepentingan alam. Contoh: menanam pohon sedini mungkin walaupun kita belum merasakan manfaatnya sekarang, namun itu sangat berguna bagi generasi selanjutnya., serta menanam pohon tanpa mengharapkan imbalan/tanpa pamrih.

\section{- Prinsip tidak merugikan (no harm)}

Karena alam yang kita milik bersama tentu satu sama lainnya tidak saling merugikan untuk itu kita sebagai manusia tidak perlu melakukan tindakan yang merugikan atau mengancam eksistensi makhluk hidup lain di alam semesta. Contoh: Saat menangkap ikan tidak menggunakan bom/pukat harimau, melakukan tebang pilih pohon,tidak mnebangi hutan sembarangan tidak membuang sampah sembarangan.

\section{- Prinsip hidup sederhana dan selaras dengan alam}

Yang dimaksud dengan prinsip ini adalah bahwa nilai-nilai kualitas hidup hendaklah bisa disesuaikan dengan alam yang menekankan pada nilai, kualitas, cara hidup, dan bukan kekayaan, sarana,standard material. Contoh: Tidak berlebihan dalam menggunakan sumber daya alam;seperti penggunaan kertas, kurangi menggunakan alat-alat yang dapat merusak lingkungan; seperti penggunaan $\mathrm{AC}$, kulkas, parfum semprot, dan lain lain.

\section{- Prinsip keadilan}

Prinsip keadilan disini bukan saja adil sesama manusia namun kita sebagai manusia hendaklah tidak melakukan yang merugikan terhadap alam. Contoh: Memberikan sangsi yang tegas terhadap perusak lingkungan hidup.

\section{- Prinsip demokrasi}

Demokrasi justru memberi tempat seluas-luasnya bagi perbedaan, keanekaragaman, dan pluralitas. Contoh: Memerhatikan lingkungan sekitar, baik berupa multikulturalisme, diverifikasi pola tanam, diversifikasi pola makan, dan sebagainya.

\section{- Prinsip integrasi moral}

Prinsip ini menuntut pejabat publik agar mempunyai sikap dan prilaku moral yang terhormat serta memegang teguh untuk mengamankan kepentingan publik yang terkait dengan sumber daya alam. Contoh: Orang yang diberi kepercayaan untuk melakukan analisis mengenai dampak lingkungan, seperti pejabat publik harus menjalankan tugasnya demi terciptanya kelestarian lingkungan hidup kita. (ilmugeografi.com).

Dari hasil wawancara dengan dengan apart desa dan masyarakat setempat bahwa kesadaran akan lingkungan hidup pada masyarakat desa Bukit Telago masih kurang hal ini disebabkan karena masih memandang bahwa lingkungan hidup sebagai sesuatu yang alami sehingga biar berjalan sebagai mana adanya. Untuk itu hendaknya adanya komitmen yang tegas dari pemerintah setempat dan masyarakat serta pengusaha lokal dengan memperhatikan dan mengimplemenntasikan kesembilan prinsip dalam menjaga lingkungan hidup agar konsisten dalam memberikan kesadaran kepada masyarakat desa Bukit Telago secara terus menerus dan berkala sehingga alam semakin dekat dengan kita sebagai manusia dan semakin harmonis hubungan antara alam dan kita sebagai manusia dengan demikian wisata Desa Bukit Telago akan terlihat keindahan alamnya

\section{Prinsip Kelestarian Budaya}

Indonesia yang terdiri dari 34 provinsi tersebar ribuan pulau dari barat sampai ke timur sangat kaya akan budaya. Salah satu budaya yabg dapat dikembangkan di desa Talago adalah budaya berselang tauh budaya ini berupa tarian dan lagu daerah. Ini harus 
dipertahankan dan dilestarikan oleh masyarakat setempat. Menurut Jacobus Ranjabar (2006:114), pelestarian budaya adalah pelestarian sebagai kegiatan atau yang dilakukan secara terus menerus, terarah dan terpadu guna mewujudkan tujuan tertentu yang mencerminkan adanya sesuatu yang tetap dan abadi, bersifat dinamis, luwes, dan selektif. Sedang menurut Gede Pitana dalam Suska, (2003) dikatakan bahwa budaya merupakan sesuatu benda atau hasil budi dan daya manusia yang agar tetap terjaga tentunya harus digunakan secara terus menerus. Berdasarkan hasil wawancara dengan pejabat kantor parawisata kabupaten Bungo, prinsip pelestarian budaya dalam strategi pengembangan wisata desa Bukit Telago maka harus adanya kerjasama antara pemerintah dan pengelola atau pegusaha setempat serta masyarakat di sekitarnya, melalui pendidikan formal maupun non formal.

\section{Prinsip Pemerataan Pendapatan}

Dengan perubahan perilaku masyarakat Bukit Telago menyadari akan potensi yang ada disekitar dan memberikan dampak ekonomi secara mikro bagi masyarakat. Dengan demikian akan terciptalah pembagian pendapatan yang merata. Kesejahteraan masyarakat dapat tercapai apabila terdapat kebijakan pemerataan pendapatan (menurut Menteri Kordinator bidang Perekonomian pada Kabinet Indonesia Maju, Darmin Nasution). Ada tiga prinsip utama dalam pemerataan pendapatan Yang pertama adalah prinsip keadilan yang sama prinsip ke dua adalah pendidikan dan pelatihan kapasitas sumberdaya manusia dalam hal ini termasuk pelatihan kejujuran dan kewirausahaan dan prinsip yang ke tiga adalah prinsip pemanfaatan pajak yang akan di alokasikan untuk program padat karya dan menciptakan wirausaha (Republika.co.id, 03 Februari,2017).

Masih sedikitnya masyarakat yang yang mengenal program kewirausahaan, maka untuk itu perlu dihimbau kepada para mahasiswa untuk melakukan Kuliah Kerja Nyata (KKN) ke Desa Bukit Telago agar pikiran masyarat desa terbuka dan dapat menggali potensi yang ada. Begitupula dengan pemerintah setempat dapat memberikan kesempatan pada pengusaha dan masyarakat setempat agar sadar akan pajak sehingga terbangun usaha usaha baru dan pada akhirnya pemerataan pendapatan dapat tercapai denqan dermikian wisata Bukit Telago akan semakin dikenal oleh masyarakat sekitar, nasional bahkan internasional.

\section{Kesimpulan}

\subsection{Kesimpulan}

1. Potensi wisata Desa Bukit Telago sangatlah menjanjikan untuk dapat berkembang dengan baik, namun sampai sejauh ini masih sebagian masyarakat yang dekat dengan lokasi wisata saja yang memanfaatkan potensi wisata tersebut dalam hal ini ditandai dengan adanya aktivitas yang ada di sekitar lokasi wisata.

2. Strategi untuk pengembangan wisata Desa Bukit Telago dengan mengimplentasikan ke tiga pilar perangkat desa yaitu aparat desa masyarakat dan pengusaha menjadikan hubungan yang harmonis agar dapat melaksanakan prinsip prinsip yang terkandung dalam community based tourism.

\subsection{Saran}

1. Pemerintah desa bekerjasama dengan pihak swasta serta mahasiswa untuk memberikan pemahaman kepada masyarakat desa Bukit Telago akan kesadaran terhadap lingkungan alam, usaha dan sadar akan pajak.

2. Agar strategi potensi pengembangan wisata di desa Bukit Telago dapat secara optimal digiatkan dan dipromosikan secara terus menerus potensi keindahan alam, budaya lokal yang ada melalui media online. 


\section{Referensi}

Damanik, Janianton,( 2013:69) "Pariwisata Indonesia (Antara Peluang Dan. Tantangan)", Yogyakarta, Pustaka Pelajar.

Hadiwijoyo, Surya Sakti. (2012:68). "Perencanaan Pariwisata Perdesaan Berbasis. Masyarakat" (Sebuah Pendekatan Konsep). Yogyakarta : Graha Ilmu.

Ranjabar, Jacobus. (2006:114). Sistem Sosial Budaya Indonesia: Suatu Pengantar. Bogor: PT. Ghalia Indonesia

1) Pitana dan Diarta, (2009)," Pengantar Ilmu Pariwisata”, Penerbit Andi Yogyakarta Suansri, Potjana,(2003:14), "Community Based Tourism Handbook" (Thailand: REST Project,

\section{Internet :}

Fatma, (2016), (ilmugeografi.com)

https://brainly.co.id/tugas/5214975\#readmore.

Republika.co.id, 03 Februari,2017

Stephen Wearinga, *, Nancy Gard McGeheeb,1, Tourism Management 38 (2013) 120-130, journal homepage: www.elsevier.com/locate/tourman 